\title{
EFFECT OF HARVEST DATE AND FOLIAR APPLICATION WITH SOME MICRONUTRIENTS ON SUGAR BEET Selim,E.H.H.;M.A.E.Abdou;H.M.Sarhan and Dalia I.H.El-Geddawy Sugar Crops Res.Institute,A.R.C,Egypt
}

\section{ABSTRACT}

Two field experiments were carried out during 2006/2007and 2007/2008 seasons at the experimental Farm of El-Serw Agricultural Research Dommiata Governorate in salt clay soil to investigate the effect of harvest date after 180 and 200 days and foliar application of micronutrients as follows : control, $\mathrm{Mn}$ at concentration $0.5 \mathrm{gm} / 1$ litre, $1.0 \mathrm{gm} /$ Litre, $\mathrm{Zn}$ at concentration $1.0 \mathrm{gm} /$ Litre,1.5 gm/1Litre Fe at concentration 1.0gm/Litre ,2gm/1 Litre on, Yield and Quality of sugar beet cv.Sultany. The obtained results are summarized as follows :

1-Delaying harvest date up to 200 days significantly increased root diameter by 9.09 and $2.62 \%$, root fresh weight by 13.65 and 9.38 , TSS $\%$ by 5.06 and $4.26 \%$ in both seasons, root length by $24.97 \%$, sucrose $\%$ by $11.92 \%$,Purity $\%$ by $7.25 \%$, top yield by $15.52 \%$ root yield by $13.76 \%$, sugar yield by $25.39 \%$ in the second season compared by harvest at 180 days from sowing .

2- The foliar application of $\mathrm{Fe}$ at $2 \mathrm{~g} / \mathrm{L}$ gave the highest values of root diameter11.10 and $11.47 \mathrm{~cm}$, root fresh weight 871.37 and $744.79 \mathrm{~g}$ in both seasons, root length $23.22 \mathrm{~cm}$, in the second season, root yield $26.83 \mathrm{t} / \mathrm{fed}$ in the first season, sugar yield $4.79 \mathrm{t} / \mathrm{fed}$ in the second season , $\mathrm{Fe}$ at $1.0 \mathrm{~g} / \mathrm{L}$ gave the maximum top yield $14.97 \mathrm{t} / \mathrm{fed}$ in first season, $\mathrm{Zn}$ at $1.5 \mathrm{~g} / \mathrm{L}$ resulted the maximum sucrose $\% 17.98 \%$ in the second season.

3-There is significant effect due to the interaction between harvest date and treated of micronutrients elements on root length,root fresh weight, TSS\%, root and sugar yields

The maximum root length $23.22 \mathrm{~cm}$, root fresh weight $894.03 \mathrm{~g}$, T.S.S\% $22.43 \%$, root yield $21.39 \mathrm{t} / \mathrm{fed}$, sugar yield $4.92 \mathrm{t} / \mathrm{fed}$ were obained from the interaction between the harvest date of 200 days from sowing and treated of $\mathrm{Fe}$ at $2 \mathrm{~g} / \mathrm{L}$., There is insignifican effect due to the interaction of harvest date and treated of micronutrients elements on root diameter, sucrose percentage, purity percetage in both seasons.

\section{INTRODUCTION}

Nowadays sugar beet crop has an important position in Egyptian crop rotation not only in the fertile soils but also in the newly reclaimed areas. In addition to sugar prodiction, its products are used in producing non traditional animal feed as well as many other secondary industries. There are many factors affecting yield and quality of sucrose $\%$ as nutritional status as well as some agropractices application i.e sowing dates, sowing methods and fertilization.

Several researchers found that the delay in harvest increased sugar and purity percentages as well as root and sugar yields, while decreased impurities terms.

Harvest date may affect yields and quality of sugar beet production.root,sugar yields and quality 
increased as harvest was delayed up to 200 days from planting while top yield decreased Aly(2000), Basha and Ouda (2000)indicate that harvest date had a significant effect on root diameter ,Furthermore late harvest was better in terms of sugar yield. The increase in sugar production accompanying the delay in harvest was attributed to increase in number of roots at harvest ,root yield,sucrose and purity as well as recoverable sucrose percentage. AbouSalama and El-Sayed (2000) Gobarh Mirvat (2001), reported that the highest root yield and recoverable sugar yield (t/fed) were obtained from plants harvested at 210 days after sowing and she added that delaying harvest date 4 weeks significantly increased sucrose, purity percentage

The soil of Nile Valley, in general and the newly reclaimed areas in particular, suffer from the lack of micro-nutrients. Also their available amounts are not sufficient for sugar beet plants to yield fully. So, application of more available micro elements need to maximize the sugar beet yield .Sugar beet in common with other crops needs very small amounts of other elements .These micro - nutrients are essential for plant growth and metabolism .Zinc deficiency is one of

the most common micro -nutrients deficiencies .Zinc mainly resembles the metal component of enzyme series so many workers investigated the effects of zinc on sugar beet

Saif (1991)mentioned that soil application of $4 \mathrm{~kg} \mathrm{zn} / \mathrm{fed}$ produced the significant increase in yields of tops, roots and dry weight per plant and sugar yield per fed. Tolova and Penova (1992) estimated the concentration of $\mathrm{B}$ and $\mathrm{Zn}$ and $\mathrm{Mn}$ in sugar beet tops and roots at different growth stages .They found that trace elements concentrations increased in tops and decreased in roots. $\mathrm{Zn}$ concentration decreased in both parts. The greatest amount was $44.7 \mathrm{~g} / \mathrm{ha}$.

Mohamed (1993) found that the highest fresh and dry weights of roots were produced from seeds soaked in $40 \mathrm{ppm}$ combination of elements (Boron,Zinc and Manganese ) solutions for 24 hours before sowing this treatment increased photosynthetic rate ,net assimilation rate and crop growth rate,Czuba(1994) found that the effect of foliar application of INSOL which contains $\mathrm{Cu}$ and $\mathrm{Zn}$ on yield of sugar beet gave the largest yield

Safronovskaya(1998), found that soil application with $0.05,0.10,0.15$ or $3.0 \mathrm{~kg}$ $\mathrm{Zn} / \mathrm{ha}$ showed that root $\mathrm{Zn}$ contents remained similar during growth but the leaf $\mathrm{Zn}$ uptake was highest at leaf canpoy closure. At this growth stage , Zn uptake increased as applied $\mathrm{Zn}$ rate increased but this was not reflected in root yield .Gezgin et al (2000)revealed the effect of four levels of Zinc fertilization (zero, $10,20,40 \mathrm{~kg} / \mathrm{ha}$ they found that there had no effect on sugar content\% of sugar beet .while there were significant differences between $\mathrm{Zn} \times$ $B$ interactions for sugar content values, while the highest sugar content value $19.9 \%$ was obtained with using $20 \mathrm{~kg} \mathrm{Zn} / \mathrm{ha}+20 \mathrm{~kg} \mathrm{~B} / \mathrm{ha}$, Elwan et al (2001) indicate that $\mathrm{Zn}$ was more effective than $\mathrm{Cu}$ on total fresh and dry weigt chlorophyll content increased by Zinc treatments Omran et al (2002) ,indicate that the most effective fertilization treatment was soil application of $\mathrm{Zn}(0.5 \%)$ accompanied with the highest rate of Boric acid $(0.10 \%)$ which promoted the growth of sugar beet and produced the highest sucrose and sugar yield .The highest extractable percentage as well as sugar coefficient 
was obtained by the same treatment. On the other hand they reveal that $\mathrm{Zn}$ as well as application either alone or in combination induced an increase in dry weights of both root and top. The effect was more pronounced by higher rate of foliar application of $B$ particularly when it was accompanied with soil application of Zinc. They added that as insignificant decrease in the concentration of $\mathrm{K}$ and $\mathrm{Na}$ and this decrease were more pronounced by using Zinc soil application when accompanied with the highest rate of foliar application of Boron recording $5.30 \%$ and $1.30 \%$ for $\mathrm{K}$ and Na respectively while amino $\mathrm{N}$ was affected by all treatments

\section{MATERIALS AND METHODS}

Two field experiments were carried out at Al-Serw Agricultural Research Station during 2006/2007 and 2007/2008 seasons to study the effect of harvest date and foliar application of micronutrients on yield and quality of sugar beet cv.Sultany.

A split plot design with three replications was adopted. The main plots were occupied by harvest date after 180 and 200 days. The sub plots occupied with foliar application of micronutrients as follows : control, $\mathrm{Mn}$ at concentration $0.5 \mathrm{gm} / 1$ litre, $1.0 \mathrm{gm} / \mathrm{Litre}, \mathrm{Zn}$ at concentration (1.0gm/Litre, 1.5 $\mathrm{gm} / 1$ Litre ) $\mathrm{Fe}$ at concentration (1.0gm/Litre, $2 \mathrm{gm} / 1$ Litre ) on yield and quality of sugar beet

Each plot experimental unit consisted of 5 ridges, $60 \mathrm{~cm}$ apart and $3.5 \mathrm{~m}$ length,occupying area of $10.5 \mathrm{~m}^{2}$ (1/400 fed).

The preceeding crop was Rice (Oryza sativa L.) in both seasons. The texture of the experimental soils was heavy clay and poor in organic matter $(1.8 \%)$ Table 1

Table(1) Mechanical and chemical analysis of the experimental soil in seasons of 2006/2007 and 2007/2008.

\begin{tabular}{|l|c|c|}
\hline Mechanical and chemical analysis & \multicolumn{2}{|c|}{ Seasons } \\
\hline Clay\% & $\mathbf{2 0 0 6 / 2 0 0 7}$ & $\mathbf{2 0 0 7 / 2 0 0 0 8}$ \\
\hline Silt\% & 62.3 & 63.2 \\
\hline Sand\% & 22.7 & 21.6 \\
\hline Organic matter\% & 13.2 & 13.4 \\
\hline Available N( p.p.m) & 1.8 & 1.8 \\
\hline Available P(p.p.m) & 52.0 & 50.3 \\
\hline Available K (p.p.m) & 16.3 & 15.2 \\
\hline CaCo3\% & 37.7 & 36.7 \\
\hline PH & 1.9 & 2.5 \\
\hline
\end{tabular}

The aformentioned soil properties were determined according to the method described by Jackson(1967).

Seed -balls were hand sown as the usual dry method of sowing on one side of ridges, $60 \mathrm{~cm}$ apart and $25 \mathrm{~cm}$ between hills at the first week of November in both seasons.Plants were thinned to one plant / hill after 5 weeks from planting. 
Calcium super phosphate $\left(15.5 \% \mathrm{P}_{2} \mathrm{O}_{5}\right)$ and potassium at the rate of $100 \mathrm{~kg}$ in the form of potassium sulphate $(48 \% \mathrm{~K} 2 \mathrm{O})$ at the rate of $100 \mathrm{~kg} / \mathrm{fed}$ at the first irrigation .Nitrogen in the form of Urea $(46 \% \mathrm{~N})$ at the rate of 60 $\mathrm{kgN} / \mathrm{fed}$ was added in the two equal portions,before the second and third irrigations. The recommendations of ARC for sugar beet production (except the studied factors) were performed.

At maturity, ten guarded plants were taken at random from each plot to estimate the following characteristics :-

1- Root diameter $(\mathrm{cm})$

2-Root length $(\mathrm{cm})$

3-Root fresh weight/plant $(\mathrm{g}$ )

4- T.S.S \% Total soluble solids was determined by hand refractometer .

5 -Sucrose \% was determined as described by Le Docte ( 1927 ).

6-Purity percentage was calculated according to the following equation:

Purity $\%=$ Sucrose $\%$ x 100/T.S.S\%

7- Root yield ( $\mathrm{t} / \mathrm{fad}$ ) was estimated on the hole plot basis.

8-Top yield $\mathrm{t} / \mathrm{fed}$

9-sugar yield ( $t /$ fad ) was calculated according to the following equation :

Sugar yield $=$ Root yield $\times$ Sucrose \%

Data were subjected to analysis of variance as described by Gomez and Gomez (1984),.Least significant difference (LSD) test at 0.05 level was used to compare between means of treatments

\section{RESULTS AND DISCUSSION}

\section{1-Root diameter(cm) :}

Means of root diameter $(\mathrm{cm})$ of sugar beet plants in response to harvest date and foliar

application of micronutrients were listed in Table 2

Delaying harvest date up to 200days significantly increased root diameter by 9.09 and $2.62 \%$ in both seasons .Basha and Ouda (2000) confirmed these resutls.

The results given in Table 2 cleared that root diameter significantly affected by the examined micronutrients. The highest values of root diameter were $11.10,11.47 \mathrm{~cm}$ were obtained with the treatment of $\mathrm{Fe}$ at rate of $2 \mathrm{~g} / \mathrm{L}$ in both seaons, whille th minimum root diameter $9.759 .40 \mathrm{~cm}$ were resulted from the untreated of trace elements.Zinc or $\mathrm{Mn}$ at mentioned rates significantly increased root diameter compared by untreatment of trace elements in both seasons.

As shown in Table 2 there is insignificant effect of the interaction between harvest date and treatment of micronutrients elements on root diameter in both seasons.

\section{2- Root length(cm):}

Means of root length $(\mathrm{cm})$ of sugar beet plants in response to harvest date and foliar application of micronutrients were listed in Table 2 
Delaying harvest date up to 200days increased root length by 24.97 $\%$ compared with harvest at 180 days from sowing in second season, Basha and Ouda (2000) ,Gobarh (2001) came to similar results.

The results showed in Table 2 cleared that root length significantly affected by the examined

micronutrients in the second season. The highest values of root length is $23.22 \mathrm{~cm}$ was obtained with the treatment of $\mathrm{Fe}$ at rate of $2 \mathrm{~g} / \mathrm{L}$, whille th minimum root Ingth $20.43 \mathrm{~cm}$ resulted from the untreatment of trace elements in second seaon.

The results in Table 3 show that there is significant effect due to the interaction between $(\mathrm{A})$ harvest date 180 and 120 days and $(\mathrm{B})$ micronutrients treatments in the second season of 2007/2008 .The maximum root length $23.17 \mathrm{~cm}$ was obtained from the interaction between the harvest date of 200 days from sowing and treatment of $\mathrm{Fe}$ at $2 \mathrm{~g} / \mathrm{L}$., while the minimum root length was $20.48 \mathrm{~cm}$ was resulted from the interaction between harvest date of 180 days from sowing and untreated with micronutrients elements in the second season.

\section{3- Root fresh weight (g):}

Means of root fresh weight $(\mathrm{g})$ of sugar beet plants in response to harvest date and foliar application of micronutrients were listed in Table 2 Delaying harvest date up to 200 days increased root fresh weight $(\mathrm{g})$ by 13.65 and $9.38 \%$ in both seasons compared by harvest at 180 days from sowing , Basha and Ouda (2000), Gobarh (2001) came to similar results.

Results given in Table 2 cleared that root fresh weight statistically responded to the examined micronutrients.

Table( 2 )Effect of harvest date and foliar application of micronutrients on root diameter,root length and root fresh weight of sugar beet in seasons of 2006/2007 and 2007/2008

\begin{tabular}{|c|c|c|c|c|c|c|c|}
\hline \multirow{2}{*}{\multicolumn{2}{|c|}{ Teatments }} & \multicolumn{2}{|c|}{ Root diameter(cm) } & \multicolumn{2}{|c|}{ Root length (cm) } & \multicolumn{2}{|c|}{ Root fresh weight (g) } \\
\hline & & 20062007 & $2007 / 2008$ & $2005 / 2007$ & $2007 / 2008$ & $2006 / 2007$ & $2007 / 2008$ \\
\hline \multirow{2}{*}{\multicolumn{2}{|c|}{\begin{tabular}{|l||l|}
$\begin{array}{l}\text { Harvest } \\
\text { date days }\end{array}$ & A1 180 days \\
\cline { 2 - 3 } & A2 200 days \\
\end{tabular}}} & 10.12 & 10.70 & 22.47 & 19.86 & 715.552 & 582.87 \\
\hline & & 11.04 & 10.98 & 20.51 & 24.82 & 819.32 & 637.57 \\
\hline \multirow{2}{*}{\multicolumn{2}{|c|}{\begin{tabular}{|l|} 
F.Test \\
LSD0.05
\end{tabular}}} & ** & ** & NS & * & * & ** \\
\hline & & 0.62 & 0.81 & & 0.36 & 21.21 & 22.55 \\
\hline \multirow{7}{*}{\begin{tabular}{|l|} 
\\
Micronutri \\
ents g/L
\end{tabular}} & B1: control & 9.75 & 9.40 & 20.67 & 20.43 & 675.10 & 556.66 \\
\hline & $\begin{array}{l}\mathrm{B} 2: \mathrm{Mn} \text { at } 0 . \\
\mathrm{gg} / \mathrm{L}\end{array}$ & 10.78 & 11.35 & 20.18 & 22.10 & 700.38 & 573.09 \\
\hline & \begin{tabular}{ll|} 
B3Mn & at \\
$1.0 \mathrm{~g} / \mathrm{L}$ &
\end{tabular} & 10.75 & 10.23 & 21.42 & 22.90 & 732.33 & 407.59 \\
\hline & \begin{tabular}{|l|l|l}
$\begin{array}{l}B 4 Z n \\
g / L\end{array}$ & at 1.0 \\
\end{tabular} & 10.45 & 10.97 & 21.98 & 22.32 & 697.65 & 563.23 \\
\hline & 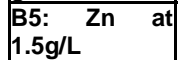 & 10.42 & 11.15 & 22.60 & 22.77 & 804.80 & 684.89 \\
\hline & $\mathrm{B} 6 \mathrm{Fe} 1.0 \mathrm{~g} / \mathrm{L}$ & 10.80 & 11.30 & 22.28 & 22.63 & 869.20 & 741.29 \\
\hline & $B 7: F e ~ 2 g / L$ & 11.10 & 11.47 & 24.78 & 23.22 & 871.37 & 744.79 \\
\hline \multicolumn{2}{|l|}{\begin{tabular}{|l|} 
F.Test \\
Snn $05 \%$
\end{tabular}} & ** & $\star \star \star$ & N.S & ** & $\star \star \star$ & 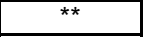 \\
\hline \multirow{2}{*}{\multicolumn{2}{|c|}{\begin{tabular}{|l|} 
LSD0.05\% \\
The Interaction AX B
\end{tabular}}} & 0.73 & 0.75 & & 1.01 & 11.21 & 12.55 \\
\hline & & NS & NS & NS & ** & NS & $\star \star *$ \\
\hline
\end{tabular}


It could be noted that application of Mn,Zinc elements gave the highest root fresh weight $(\mathrm{g})$ compared with unfetilized control. The maximum root fresh weight 871.37 and $744.79 \mathrm{~g} /$ plant were obtained from the treated of $\mathrm{Fe}$ at $2 \mathrm{~g} / 1 \mathrm{~L}$ while the minimum root fresh weight 675.10 and $556.66 \mathrm{~g}$ were resulted from the untreated with micronutrients elements in both seasons.

The results in Table 3 show that there is significant effect due to the interaction between $(\mathrm{A})$ harvest date 180 and 120 days and $(\mathrm{B})$ micronutrients treatments in the second season of 2007/2008 .The maximum root fresh weight $894.03 \mathrm{~g}$ was obtained from the interaction between the harvest date of 200 days from sowing and treated of $\mathrm{Fe}$ at $2 \mathrm{~g} / \mathrm{L}$., while the minimum root fresh were $479.67 \mathrm{~g}$ was resulted from the interaction between harvest date of 180 days from sowing and untreated with micronutrients elements in the second season Table 4.

Table(3): Effect of interaction between (A) harvest date and (B)foliar application of micronutrients on root length of sugar beet in season $2007 / 2008$

\begin{tabular}{|l|c|c|}
\hline \multirow{2}{*}{ Treatments } & A1 2007/2008 \\
\cline { 2 - 3 } & 21.48 & A2 \\
\hline B1 & 22.70 & 21.87 \\
\hline B3 & 23.77 & 23.15 \\
\hline B4 & 23.33 & 23.03 \\
\hline B5 & 23.13 & 23.30 \\
\hline B6 & 23.73 & 23.40 \\
\hline B7 & 22.17 & 23.53 \\
\hline F.Test & \multicolumn{2}{|c|}{${ }^{* *}$} \\
\hline LSD0.05 & \multicolumn{2}{|c|}{1.422} \\
\hline
\end{tabular}

Table(4): Effect of the interaction between (A) harvest date and (B)foliar application of micronutrients on root fresh weight of sugar beet in season $2007 / 2008$

\begin{tabular}{|l|c|c|}
\hline \multirow{2}{*}{ Treatments } & $\mathbf{A}$ & $\mathbf{2 0 0 7 / 2 0 0 8}$ \\
\cline { 2 - 3 } & 479.67 & $\mathbf{A 2}$ \\
\hline B1 & 432.77 & 490.67 \\
\hline B2 & 582.63 & 570.57 \\
\hline B3 & 530.27 & 589.70 \\
\hline B5 & 556.73 & 653.37 \\
\hline B6 & 652.33 & 884.40 \\
\hline B7 & 655.70 & 894.03 \\
\hline F.Test & \multicolumn{2}{|c|}{${ }^{\star *}$} \\
\hline LSD0.05 & \multicolumn{2}{|c|}{14.13} \\
\hline
\end{tabular}

\section{4-Total Soluble Solids\%:}

Means of TSS\% of sugar beet plants in response to harvest date and foliar application of micronutrients were listed in Table 5

Delaying harvest date up to 200 days increasedTSS\% by 5.06 and $4.26 \%$ compared with the date of harvest at 180 days from sowing in both seasons. Basha and Ouda (2000) ,Gobarh (2001) came to similar results. 
Results given in Table 2 cleared that TSS\% of sugar beet statistically responded to the examined micronutrients. It could be noted that application of Mn,Zinc elements gave the highest TSS\% in the second season.Fe at 2 $\mathrm{g} / \mathrm{L}$ significantly increased total soluble solids by $5.45 \%$ compared with unfertilized control in second season.

The results in Table 6 show that there is significant effect due to the interaction between $(\mathrm{A})$ harvest date 180 and 120 daysand(B)micronutrients treatments on total soluble solids in the second season of 2007/2008 .The maximum T.S.S\% $22.43 \%$ was obtained from the interaction between the harvest date of 200 days from sowing and treated of $\mathrm{Fe}$ at $2 \mathrm{~g} / \mathrm{L}$., while the minimum root fresh were $21.05 \%$ was resulted from the interaction between harvest date of 180 days from sowing and untreated with micronutrients elements in the second season.

\section{5- Sucrose\%:}

Means of Sucrose\% of sugar beet plants in response to harvest date and foliar application of micronutrients were listed in Table 5

Delaying harvest date up to 200 days increased sucrose by $11.92 \%$ compared by the date of harvest at 180 days from sowing) in second season , Basha and Ouda (2000) ,Gobarh (2001) came to similar results

Results given in Table 5 cleared that sucrose \% statistically responded to the examined micronutrients.It could be noted that application of Mn,Zinc elements gave the highest sucrose $\%$,the maximum sucrose $\% 17.98 \%$ was obtained with the treated of $\mathrm{Zn}$ at $1.5 \mathrm{~g} / \mathrm{L}$ in the second season, while the lowest sucrose $\% 16.15 \%$ was obtained from the untreated of micronutrients in the second season.

As shown in Table 5 there are insignificant effect of the interaction of harvest date and treated of micronutrients elements on sucrose percentage in both seasons.

\section{6-Purity\%:}

Means of purity\%of sugar beet plants as affected by harvest date and foliar application of micronutrients elements were listed in Table 5

Delaying harvest date up to 200 days increased Purity\% by $7.25 \%$ compared by the first date in second season. Basha and Ouda (2000) ,Gobarh (2001) came to similar results.

Treatments of micronutrients of $\mathrm{Mn}, \mathrm{Zn}$ and Fe elements significantly increased purity percentage compared by untreatmed of micronutriens elements in both seasons.

Treatment of $\mathrm{Zn}$ at $1.5 \mathrm{~g} / \mathrm{L}$ resulted maximum purity percentage $82.52 \%$ in the second season while the untretment with micronutrients gave the minimum purity percentage 76.35 and $76.55 \%$ in both seasons.

Table 5 reveal that there is insignificant effect of the interaction between harvest date and treatment of micronutrients elements on purity percentage in both seasons. 
Table(5): Effect of harvest date and foliar application of micronutrients on Total Soluble Solids, Sucrose \% and Purity \% in in seasons of 2006/2007 and 2007/2008 .

\begin{tabular}{|c|c|c|c|c|c|c|c|}
\hline \multirow{2}{*}{\multicolumn{2}{|c|}{ Teatments }} & \multicolumn{2}{|c|}{ TSS $\%$} & \multicolumn{2}{|c|}{ Sucrose $\%$} & \multicolumn{2}{|c|}{ Purity\% } \\
\hline & & 20062007 & $2007 / 2008$ & 2006/2007 & $2007 / 2008$ & $2006 / 2007$ & $2007 / 2008$ \\
\hline Harvest & A1 180 days & 21.03 & 21.05 & 16.93 & 16.29 & 80.51 & 77.39 \\
\hline date days & A2 200 days & 22.11 & 21.95 & 16.77 & 18.23 & 75.23 & 83.00 \\
\hline F.Test & & * & ** & NS & * & NS & ** \\
\hline \begin{tabular}{|l} 
LSD0.05 \\
\end{tabular} & & 0.49 & 0.40 & & 079 & & 0.97 \\
\hline & B1: control & 21.08 & 21.10 & 16.09 & 16.15 & 76.35 & 76.55 \\
\hline Micronutr & $\begin{array}{l}\text { B2: } \mathrm{Mn} \text { at } 0 . \\
5 \mathrm{~g} / \mathrm{L}\end{array}$ & 21.78 & 21.13 & 16.89 & 17.40 & 77.57 & 81.69 \\
\hline ents g/L & $\begin{array}{|ll|}\mathrm{B} 3 \mathrm{Mn} & \text { at } \\
1.0 \mathrm{~g} / \mathrm{L} & \\
\end{array}$ & 21.78 & 20.86 & 16.44 & 17.20 & 75.48 & 82.47 \\
\hline & \begin{tabular}{|l|} 
B4Zn at 1.0 \\
$\mathrm{~g} / \mathrm{L}$
\end{tabular} & 21.79 & 21.46 & 16.94 & 17.22 & 77.76 & 80.17 \\
\hline & \begin{tabular}{|l|} 
B5: Zn at \\
$1.5 \mathrm{~g} / \mathrm{L}$
\end{tabular} & 21.84 & 21.79 & 17.09 & 17.98 & 78.28 & 82.52 \\
\hline & $\begin{array}{|ll|}\mathrm{B} 6 & \mathrm{Fe} \\
1.0 \mathrm{~g} / \mathrm{L} & \\
\end{array}$ & 21.17 & 21.91 & 17.44 & 17.00 & 80.31 & 77.58 \\
\hline & B7 : Fe 2g/L & 21.48 & 22.25 & 17.05 & 17.88 & 79.34 & 80.38 \\
\hline F.Test & & NS & *夫 & $\mathrm{NS}$ & 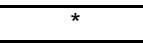 & * & *夫 \\
\hline LSD0.05\% & & & 0.60 & & 1.24 & 3.26 & 3.28 \\
\hline The Intera & ction A X B & NS & ** & NS & NS & NS & NS \\
\hline
\end{tabular}

Table(6): Effect of the interaction between (A) harvest date and (B)foliar application of micronutrients on T.S.S\% of sugar beet in season $2007 / 2008$

\begin{tabular}{|l|c|c|}
\hline \multirow{2}{*}{ Treatments } & A1 2007/2008 \\
\cline { 2 - 3 } & 21.05 & A2 \\
\hline B1 & 20.80 & 21.75 \\
\hline B3 & 20.91 & 21.47 \\
\hline B4 & 21.04 & 20.80 \\
\hline B5 & 21.96 & 21.87 \\
\hline B6 & 22.67 & 21.02 \\
\hline B7 & 22.07 & 21.16 \\
\hline F.Test & \multicolumn{2}{|c|}{0.851} \\
\hline LSD0.05 & \multicolumn{2}{|c|}{0.43} \\
\hline
\end{tabular}

\section{7- Top yield(t/fed):}

Top yield was significantly affected by harvest date in the second season as shown in Table 7

Harvest sugar beet crop at 200 days significantaly increased top yield by $15.52 \%$ compared

with the first date (180 days from sowing ), while there was insignificant effect on top yield in the first season Table 7 Basha and Ouda (2000) ,Gobarh (2001) came to similar results.

Foliar micronutrients elements of $\mathrm{Mn}, \mathrm{Zn}$ and $\mathrm{Fe}$ on sugar beet plants significantly increased top yield in the second season The maximum results of top yield $14.97 \mathrm{t} /$ fedresulted from treated of $\mathrm{Fe}$ at 
$1.0 \mathrm{~g} / \mathrm{L}$ while the minimum top yield $9.87 \mathrm{t} /$ fed resulted from the untreated with foliar of trace elements in first season.

As shown in Table 7 there is insignificant effect of the interaction between harvest date and treatmed of micronutrients elements on top yield in both seasons

\section{8-Root yield ( $\mathrm{t} / \mathrm{fed})$}

Means of root yield ( $\mathrm{t} / \mathrm{fed}$ ) of sugar beet plants in response to harvest date and foliar application of micronutrients were listed in Table 7 Delaying harvest date up to 200 days increased root yield (t/fed) by $13.76 \%$ compared by harvest at 180 days from sowing in the second season , Basha and Ouda (2000) ,Gobarh (2001) came to similar results.

Results given in Table 7 cleared that root yield statistically responded to the examined micronutrients. It could be noted that application of Mn,Zinc and $\mathrm{Fe}$ elements gave the highest root yield compared with unfetilized control . The maximum root yield $26.83 \mathrm{t} / \mathrm{fed}$ was resulted from using $\mathrm{Fe}$ at $1 \mathrm{~g} / \mathrm{L}$ in the second season.while the minimum root yield $18.63 \mathrm{t} / \mathrm{fed}$ resulted from the unfertilized by trace elements in the first season

The results in Table 8 show that there is significant effect due to the interaction between $(\mathrm{A})$ harvest date 180 and 120 days and(B)micronutrients treatments on root yield in the second season of 2007/2008.The maximum root yield $21.39 \mathrm{t} / \mathrm{fed}$ was obtained from the interaction between the harvest date of 200 days from sowing and treated of $\mathrm{Fe}$ at $2 \mathrm{~g} / \mathrm{L}$., while the minimum root yield $17.29 \mathrm{t} / \mathrm{fed}$ was resulted from the interaction between harvest date of 180 days from sowing and untreated with micronutrients elements in second season.

Table(7): Effect of harvest date and foliar application of micronutrients on Top ,root and sugar yields ( $t / f e d)$ of sugar beet in seasons of 2006/2007 and 2007/2008

\begin{tabular}{|c|c|c|c|c|c|c|c|}
\hline \multirow{2}{*}{\multicolumn{2}{|c|}{ Teatments }} & \multicolumn{2}{|c|}{$\begin{array}{l}\text { Top yield } \\
\text { (t/fed) }\end{array}$} & \multicolumn{2}{|c|}{$\begin{array}{c}\text { Root yield } \\
\text { (t//fed) }\end{array}$} & \multicolumn{2}{|c|}{$\begin{array}{c}\text { Sugar yield } \\
(\mathrm{t} / \mathrm{fed})\end{array}$} \\
\hline & & 20062007 & $2007 / 2008$ & $2006 / 2007$ & $2007 / 2008$ & $2006 / 2007$ & $2007 / 2008$ \\
\hline \multirow{2}{*}{$\begin{array}{l}\text { Harvest } \\
\text { date days }\end{array}$} & A1 180 days & 9.25 & 12.03 & 19.72 & 22.05 & 3.34 & 3.59 \\
\hline & A2 200 days & 10.33 & 13.89 & 19.38 & 25.08 & 3.31 & 4.50 \\
\hline \multicolumn{2}{|l|}{ F.Test } & NS & $\star \star$ & NS & * & NS & $\star \star$ \\
\hline \multicolumn{2}{|l|}{ LSD0.05 } & & 0.34 & & 1.35 & & 0.27 \\
\hline \multirow{7}{*}{$\begin{array}{l}\text { Micronutri } \\
\text { ents g/L }\end{array}$} & B1: control & 9.87 & 12.80 & 18.63 & 16.79 & 2.99 & 3.52 \\
\hline & $\begin{array}{l}\text { B2: } \mathrm{Mn} \text { at } 0 . \\
5 \mathrm{~g} / \mathrm{L}\end{array}$ & 9.52 & 12.61 & 19.97 & 24.73 & 3.37 & 4.30 \\
\hline & $\begin{array}{|ll|}\text { B3Mn } & \text { at } \\
1.0 \mathrm{~g} / \mathrm{L} & \\
\end{array}$ & 9.50 & 10.20 & 19.23 & 18.92 & 3.16 & 3.25 \\
\hline & \begin{tabular}{|lll}
$\mathrm{B} 4 Z \mathrm{Zn}$ & at & 1.0 \\
$\mathrm{~g} / \mathrm{L}$
\end{tabular} & 9.45 & 12.31 & 18.80 & 24.29 & 3.18 & 4.18 \\
\hline & $\begin{array}{ll}\text { B5: Zn at } \\
\text { 1.5g/L }\end{array}$ & 9.82 & 13.27 & 19.62 & 26.57 & 3.35 & 4.78 \\
\hline & B6 Fe 1.0g/L & 9.28 & 14.97 & 19.47 & 26.83 & 3.39 & 4.56 \\
\hline & B7 : Fe 2g/L & 11.10 & 14.59 & 21.16 & 26.81 & 3.61 & 4.79 \\
\hline \multicolumn{2}{|l|}{ F.Test } & NS & $\star \star \star$ & NS & * & NS & $\star \star \star$ \\
\hline \multicolumn{2}{|l|}{ LSD0.05\% } & & 0.59 & & 1.52 & & 0.44 \\
\hline \multicolumn{2}{|c|}{ The Interaction A X B } & NS & NS & $\overline{\mathrm{NS}}$ & $\star \star$ & $\overline{\mathrm{NS}}$ & ** \\
\hline
\end{tabular}


Table(8): Effect of the interaction between (A) harvest date and (B)foliar application of micronutrients on root yield ( $t / f e d)$ of sugar beet in season 2007/2008.

\begin{tabular}{|l|c|c|}
\hline \multirow{2}{*}{ Treatments } & \multicolumn{2}{|c|}{$\mathbf{2 0 0 7 2 0 0 8}$} \\
\cline { 2 - 3 } & A1 & A2 \\
\hline B1 & 17.29 & 19.96 \\
\hline B2 & 18.79 & 21.14 \\
\hline B3 & 19.92 & 18.54 \\
\hline B4 & 20.21 & 17.39 \\
\hline B5 & 20.72 & 18.51 \\
\hline B6 & 20.19 & 18.75 \\
\hline B7 & 20.92 & 21.39 \\
\hline F.test & \multicolumn{2}{|c|}{ ** } \\
\hline LSD 0.05 & \multicolumn{2}{|c|}{2.03} \\
\hline
\end{tabular}

\section{9- Sugar yield(t/fed):}

Means of sugar yield $t / f e d$ of sugar beet plants in response to harvest date and foliar application of micronutrients were listed in Table 7

Delaying harvest date up to 200 days increased sugar yield (t/fed) by $25.39 \%$ compared with the first date of 180 days in the second season, Basha and Ouda (2000) Gobarh (2001) came to similar results.

Results given in Table 7 cleared that sugar yield statistically responded to the examined micronutrients.It could be noted that application of Mn,Zinc and $\mathrm{Fe}$ elements gave the highest sugar yield compared with unfetilized control. The maximum sugar yield $4.79 \mathrm{t} / \mathrm{fed}$ resulted from treatment of $\mathrm{Fe}$ at rate of $2 \mathrm{~g} / \mathrm{L}$ and $\mathrm{Zn}$ at $1.5 \mathrm{~g} / \mathrm{L}$ gave sugar yield of $4.78 \mathrm{t} / \mathrm{fed}$ ) while the minimum sugar yield $2.99 \mathrm{t} /$ fed resulted from the untreated material with trace elements in second season.

The results in Table 9 show that there is significant effect due to the interaction between(A) harvest date (180 and 120 days) and(B)micronutrients treatments on sugar yield in second season of 2007/2008 .The maximum sugar yield $4.92 \mathrm{t} / \mathrm{fed}$ was obtained from the interaction between the harvest date of 200 days from sowing and treatment of $\mathrm{Fe}$ at $2 \mathrm{~g} / \mathrm{L}$., while the minimum sugar yield $2.22 \mathrm{t} / \mathrm{fed}$ )was resulted from the interaction between harvest date of 180 days from sowing and untreated material with micronutrients elements in second season.

Table(9): Effect of interaction between (A) harvest date and micronutrients on sugar yield ( $t / f e d)$ of sugar beet in season 2007/2008.

\begin{tabular}{|l|c|c|}
\hline \multirow{2}{*}{ Treatments } & \multicolumn{2}{|c|}{$\mathbf{2 0 0 7 / 2 0 0 8}$} \\
\cline { 2 - 3 } & $\mathbf{A 1}$ & $\mathbf{A 2}$ \\
\hline B1 & 2.22 & 3.74 \\
\hline B2 & 3.34 & 3.79 \\
\hline B3 & 3.50 & 3.41 \\
\hline B4 & 3.49 & 3.16 \\
\hline B5 & 3.72 & 377 \\
\hline B6 & 3.77 & 3.52 \\
\hline B7 & 3.80 & 4.92 \\
\hline F.test & \multicolumn{2}{|c|}{ ** } \\
\hline LSD 0.05 & \multicolumn{2}{|c|}{$\mathbf{3 . 6 5}$} \\
\hline
\end{tabular}




\section{REFERRENCES}

Abou - Salama,A.M andS.J El-Syiad (2000).Studies on some sugar beet cultivars under middle Egypt conditions. 1.Response to planting date and harvestingdates.Assuit J.Agric.Sci.,31(1):137-159.

Aly,E.F.A. (2000) Factors affecting yield of someSugar beet varieties in newly reclaimed soils M.Sc.Thesis.Fac . Agric. Cairo Univ.,Egypt.

Basha,H.A. andM.M. Ouda (2000). Effect of sowing method,phosphorus fertilization and harvesting time on yield and qualityof sugar beet in newly cultivated sandy soil ZagazigJ. Agric. Res., 27(1):43-57.

Czuba,R. (1994). The results of foliar nutrition of field crops. II-Response of plants to foliar application of trace elements or nitrogen combined with trace elements. or nitrogen combined with trace elements. RocznikiGleboznzwcze.1994,45:3-4,79-87;4 ref

Elwan ,I.M;Zeinab Ramadan, and Shafika Nasr,M(2001), Effect of copper and zinc fertilizer Application on growth,chemical and biochemical contents of sugar beet plants Zagazig J.Agric. Res.; 28(2):367-380.

Gezgin,S.; B.Sade;Hamurcu;N.Dursun;M.Onder and M.Babaoglu(2000). Effect of various Boron,Zinc and N P K levels on the yield and sugar content of sugar beet Beta vulgaris Sacchaifera Proceeding of the international work shop, Boron,2001. UniversityBonn Germany.23- 28June 2001

Gobarh,Mirvat E. (2001) Influence of plant densities and harvest dates on growth, yield and quality of sugar beet( Beta vulgaris L,) under newly reclaimed sandy soil J.Agric. Sci. MansouraUniv.,26(10): 5905_5920,200

Gomez,K.A. and A.A.Gomez (1984).Statistical Procedures for Agricultural Research John WilleyAnd Sons.Inc,New York,U.S

Jackson,M.L .(1967). Soil chemical Analysis . Premtice-Hall of India Priva Ltd., New Delhi Le Docte . A . ( 1927 ) . Commercial determination of sugar in the root using the Sachr - Le Docte Prosses Inter. Sugar J . $29: 488-492$.

Omran, E.H.Samya; H.El_Guibali Amal.,and KH.Abou Shady. (2002). Effect of zinc and Bor application at different rates and methods on sugar beet plants.Annals of Agric.Sci. Moshtohor, Vol.40(3):1865- 1875.

Safronovskaya,G.M. (1998).Effect of zinc fertilizers on the productivity changes in zinc content in sugar beet at different soil acidity levels of a sod- podzolic loamy soil.Pochvovedenie-iAgrokhimiya.1998,30: 166- 171 .( C.F. Record 16 of 831- CAB Abst., 1998/082000/07).

Saif,L.M.(1991).Yield and quality of sugar beet as affected by nitrogen sources and rate of some microelements in Kafer El-sheikh. Ph.D.Thesis,Fc. of Agric.Ain Shams Univ

Snedecor, G.W. and W.G Cochran.( 1981 ) Statistical Oxford and I.B.H H publish Ing Ed. 670 PP

Tsolova,V. and Penova(1992).Absorption And extraction of microelements by sugar beet.Pachvoxnanie,Arokhimiya 27(2):35-39.Nnn. 


\section{Selim,E.H.H. et al.}

تأثير ميعاد الحصاد والرش ببعض العناصر الصغرى على بنجر السكر مجري

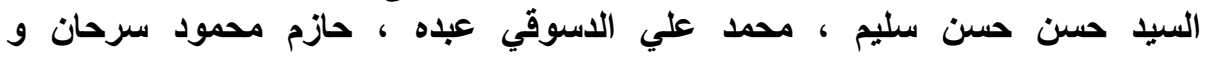
داليا ابراهيم حنفي الجداوي الجيمي معهز بحوث المحاصيل السكرية ـقسم بحوث المعاملات- مركز البحوث الزرعيةـ الجيزة ـمصر

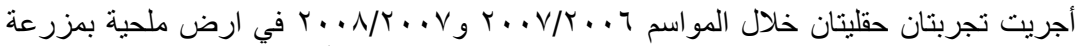

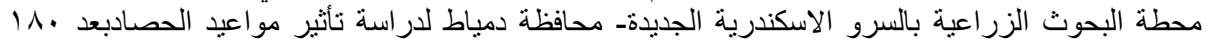

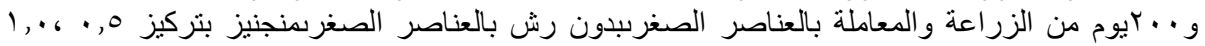

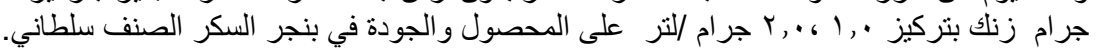

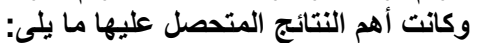

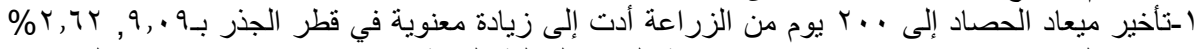

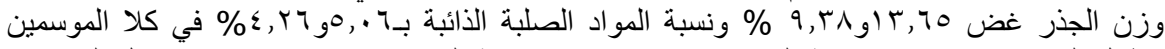

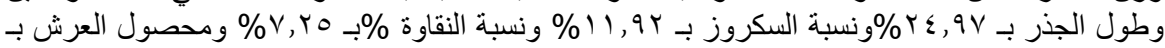

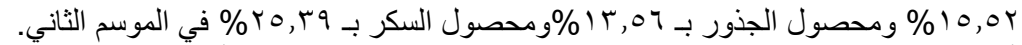

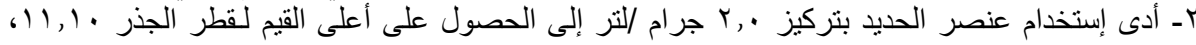

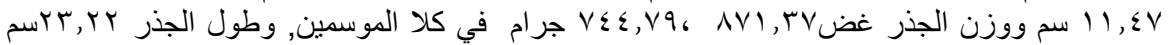

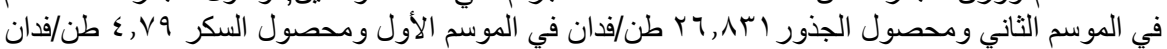

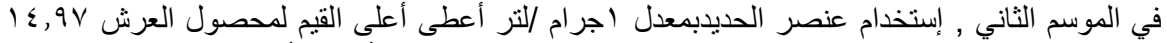
طن /فدان في الموسم الاول ، استخدام الزنك بمعدل 1, إندرام الثتر أعطى أعلى القيم لنسبة السكروز

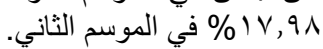

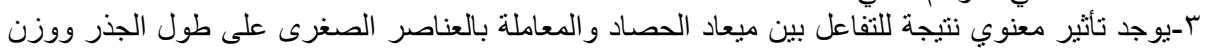

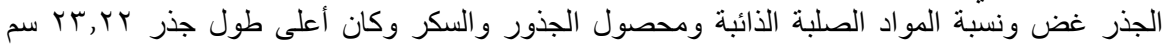

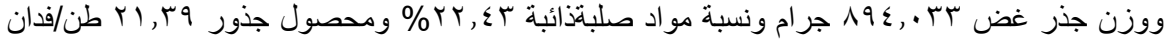

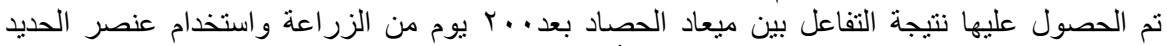

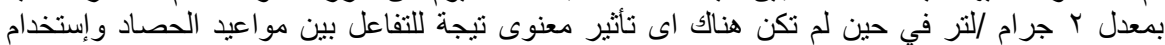

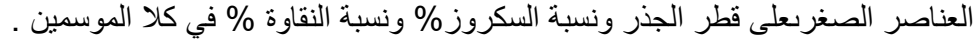

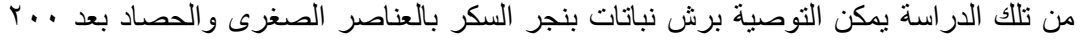

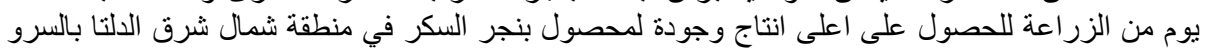

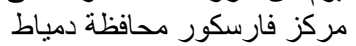

